Haapanen, L., L. Kääntä \& L. Lehti (toim.) 2018. Diskurssintutkimuksen menetelmistä. On the methods in discourse studies. AFinLA-e. Soveltavan kielitieteen tutkimuksia 2018/n:o 11. 114-136.

\author{
Melisa Stevanovic ${ }^{1}$ \& Elina Weiste ${ }^{2}$ \\ ${ }^{1}$ Helsingin yliopisto, ${ }^{2}$ Työterveyslaitos
}

\title{
Keskustelunanalyysi ja fokusryhmien diskursiivinen tutkimus
}

We introduce a focus-group approach where we draw on a combination of discursive focus-group research and conversation analysis. We explore how the analysis of focus-group talk may attend equally to the content of the group members' talk and to the interactional dynamics of that talk. Essentially, we propose that the notions of social praxis and action allow researchers to consider focus-group data as a window to the social world that pre-exists the focus-group encounter. However, this world is accessible to the researcher only through the local organization of action in the encounter, which needs to be taken as the priority of analysis. In eliciting maximally spontaneous and minimally interview-led talk around the research topic, we demonstrate the fruitfulness of using stimulus material in the research encounters. The end part of the paper consists of examples of data analysis, through which we illustrate our approach.

Keywords: focus groups, conversation analysis, discursive research Asiasanat: fokusryhmät, keskustelunanalyysi, diskursiivinen tutkimus 


\section{Johdanto}

Fokusryhmien (focus groups) käyttö on suosittua laadullisessa tutkimuksessa. Menetelmässä on keskeistä valikoitujen osallistujien välillä tapahtuva ryhmäkeskustelu, jota tutkija pitää yllä ennalta suunnitellun haastattelurungon pohjalta tai ikään kuin tarjoilee tiettyjä tutkimuksen kohteena olevia teemoja tutkittavien keskenään keskusteltaviksi ja kommentoitaviksi (Bloor ym. 2001; Fern 2001). Fokusryhmiä hyödyntävät tutkimukset poikkeavat toisistaan siinä, missä määrin keskustelu tapahtuu tutkijan ja kunkin ryhmäläisen välillä (ryhmähaastattelu) tai lähes yksinomaan ryhmäläisten kesken (ryhmäkeskustelu) (Kitzinger \& Barbour 1999; Pietilä 2017). Fokusryhmiä hyödynnettäessä tyypillistä kuitenkin on, että ryhmän vetäjät tukevat, rohkaisevat ja kannustavat ryhmäläisiä ottamaan harteilleen ainakin osan keskustelun vetovastuusta (Madriz 2000). Fokusryhmähaastattelujen tutkimuksen päämäärä on sama kuin muissakin laadullisissa tutkimuksissa - tutkittavan ilmiön syvällinen ymmärtäminen. Fokusryhmähaastattelujen tuottaman rikkaan ja monipuolisen aineiston ajatellaan soveltuvan moniin tarkoituksiin mutta aivan erityisen hyvin kehittämistyöhön (ks. esim. Mäntyranta \& Kaila 2008).

Fokusryhmäaineistoja on usein analysoitu kuten yksilöhaastatteluja eli keskittyen haastateltavien puheen teemoihin ja sisältöihin, jolloin tutkimuksen tavoitteena on ollut selvittää tutkittavien näkemyksiä, kokemuksia tai mielipiteitä eri asioista. Fokusryhmäaineistot tarjoavat kuitenkin erinomaisen mahdollisuuden myös ryhmän jäsenten välisen vuorovaikutuksen tarkasteluun (Wilkinson 1998; Morgan 2010). Ryhmäkeskusteluja ei näin ollen voi nähdä monistettuina yksilöhaastatteluina, vaan ryhmän vuorovaikutus voidaan ymmärtää piirteeksi, joka nimenomaan tekee aineistosta erityistä (Kitzinger \& Barbour 1999; Pietilä 2017). Esimerkiksi vaikeneminen tietyistä aiheista muun ryhmän edessä saattaa tuottaa tutkijoita kiinnostavaa tietoa (Hollander 2004). Ryhmäkeskusteluissa osallistujat käyttävät yleensä arkikielen ilmaisuja, joiden he olettavat olevan muille ryhmäläisille ymmärrettäviä, jolloin valitut sanat ja ilmaukset voivat olla joidenkin tutkimuskysymysten näkökulmasta kiinnostavia (Sulkunen 1990). Yksilöiden henkilökohtaisten näkemysten ja mielipiteiden sijasta tutkijat saattavat myös olla kiinnostuneita nimenomaan ryhmän yhteisistä normeista ja ihanteista (ks. esim. Wight 1994). Tällöin fokusryhmäaineistot antavat mahdollisuuden tutkia, kuinka jaettuja ryhmäkeskustelussa esitetyt ajatukset ovat ja mitä tapahtuu, jos joku poikkeaa odotuksista.

Tässä artikkelissa keskitymme fokusryhmien vuorovaikutukseen havainnollistamalla lähestymistapaa, jossa fokusryhmähaastattelujen analyysiin yhdistetään työkaluja fokusryhmien diskursiivisesta tutkimuksesta (Agar \& MacDonald 1995; Edley \& Wetherell 1997; Frith \& Kitzinger 1998; Wilkinson 1998; Smithson 2000; Duggleby 2005; Morgan 2010; Grønkjær ym. 2011) ja keskustelunanalyysista (Schegloff 2007; Sidnell 2010; Clift 2016; Stevanovic \& Lindholm 2016). Ottaen huomioon näiden kahden tutkimussuuntauksen erilaiset analyyttiset painopisteet yhtäältä kes- 
kustelun sisällön ja toisaalta vuorovaikutusdynamiikan analyysissa tässä artikkelissa esittelemäämme lähestymistapaa leimaa pyrkimys etsiä keinoja operoida näiden painopisteiden välimaastossa (ks. esim. Wilkinson \& Kitzinger 2003). Näitä kahta tutkimustraditiota hyödyntämällä tavoitteenamme on tarjota fokusryhmien tutkimukseen uusia keinoja syventää vuorovaikutuksessa rakentuvien merkitysten analyysia.

\section{Yhteisten merkitysten rakentaminen ja vuorovaikutuksen käytänteet}

Kielenkäyttö ei ainoastaan kuvaa maailmaa, vaan samalla myös rakentaa, jäsentää ja merkityksellistää sitä. Myös näennäisen neutraalit kielelliset ilmaukset lataavat kohteisiinsa piileviä odotuksia siitä, mikä on luonnollista (Jokinen ym. 2016: 27). Diskursiivinen tutkimus pyrkii tekemään näkyväksi tällaisten ulkoisten konstruktioiden kirjoa, joilla sosiaalista todellisuutta rakennetaan (Fairclough 1992: 41). Sosiaalisen konstruktionismin teoriaan (Berger \& Luckmann 1967) nojaten merkitysten ajatellaan muodostuvan suhteessa toinen toisiinsa. Näin sosiaalinen todellisuus hahmottuu monenlaisten rinnakkaisten ja keskenään kilpailevien merkityssysteemien kentäksi (Potter \& Wetherell 1987: 146-157). Sosiaaliseen konstruktionismiin nojaavassa diskursiivisessa tutkimuksessa korostetaan, etteivät kielellisten kategorioiden merkitykset, merkityssysteemit ja diskurssit kumpua sattumanvaraisesti yksilöistä vaan kysymys on kulttuurisista resursseista, jotka rakentuvat osana erilaisia historiallisesti muotoutuneita toiminta- ja työskentelytapoja eli sosiaalisia käytäntöjä.

Diskursiivisen tutkimuksen kenttä on laaja, ja se pitää sisällään monenlaisia tarkastelun painopisteitä ja tutkimuksellisia orientaatioita (ks. esim. Jokinen \& Juhila 2016). Yksi tällainen tutkimussuuntaus on kategoria-analyysi, jossa kiinnitetään huomiota siihen, millaisia kategorisia ilmauksia ihmiset käyttävät itsestään sekä ympärillään olevista ihmisistä, asioista ja esineistä ja kuinka he hyödyntävät näihin luokitteluihin sisältyvää kulttuurista tietoa omiin tarkoitusperiinsä (ks. esim. Jayyusi 1984; Juhila ym. 2012). Etnometodologisen tradition sisällä kategorian käsitettä kehittäneen Harvey Sacksin (1992) mukaan ihmiset tunnistetaan sijoittamalla heidät tiettyihin jäsenyyskategorioihin (membership categories), jotka puolestaan järjestyvät joukoiksi (isä, äiti, lapset) ja pareiksi (nainen ja mies), samalla kun kuhunkin kategoriaan liitetään tietynlaisia toimintoja (Jokinen \& Juhila 2016: 283-284). Diskursiivisen psykologian nimellä tunnetussa tutkimussuuntauksessa päähuomio on puolestaan psykologisia ilmiöitä koskevissa kategorioissa: kuinka tunteisiin, asenteisiin, ajatuksiin ja muistiin viittaamista käytetään puheessa retorisena keinona (esim. Edwards \& Potter 1992). Näissä lähestymistavoissa toimija tulkitsee ja tuottaa yhdessä muiden kanssa järjellistä ja merkityksellistä toimintaa sekä suhteuttaa tekemisensä jaettuihin käsityksiin ja vakiintuneisiin käytäntöihin. Tästä näkökulmasta sosiaalinen todel- 
lisuus näyttäytyy asiana, jota ylläpidetään ennen kaikkea sosiaalisessa vuorovaikutuksessa.

Sosiaalisen todellisuuden ylläpitämisen prosessien tutkimuksessa fokusryhmien diskursiivinen tutkimus on avainasemassa (ks. Agar \& MacDonald 1995; Edley \& Wetherell 1997; Frith \& Kitzinger 1998; Wilkinson 1998; Smithson 2000; Duggleby 2005; Morgan 2010; Grønkjær ym. 2011). Koska ryhmäkeskustelun vetäjän rooli on pienempi kuin yksilöhaastattelijan suorittajan, ryhmäkeskustelut antavat tutkijalle mahdollisuuden analysoida käsitteitä, hahmottamistapoja ja argumentteja, joiden puitteissa ryhmä toimii (Pietilä 2010: 215). Kun joukko ihmisiä keskustelee keskenään, vuorovaikutuksessa tulevat näkyviksi monet itsestäänselvyydet, joihin osallistujat suuntautuvat. Suomessa esimerkiksi Valtonen (2004) tutki ryhmäkeskustelujen avulla aikaan ja vapaa-aikaan liittyviä kulttuurisia merkityksiä ja havaitsi, että television katselu, harrastukset ja kesämökki yhdistettiin lähestulkoon itsestään selvästi vapaa-aikaan. Toisaalta ryhmäkeskustelu teki näkyväksi myös ongelmallisiksi muuttuneita kulttuurisia käsityksiä. Niinpä esimerkiksi ajatukset työ- ja vapaa-ajan sekoittumisesta tai sunnuntaisesta kauppojen aukiolosta nostivat esiin moraalista kauhistelua ja puolustelua. Lisäksi ryhmätilanne toi epäsuorasti ilmi myös sellaisia asioita, kuten seksi, joita ei ollut odotuksenmukaista nostaa esiin keskusteltaessa ihmisten ajankäytöstä. (Valtonen 2005: 228.)

Merkitykset rakentuvat tapahtuma- ja toimintatilanteen kontekstissa, tietyssä ajassa ja paikassa, mutta näiden mittakaavat voivat kuitenkin vaihdella sekunnista ihmiskunnan historian mittaiseen ajanjaksoon tai neliömetristä globaaliin (Jokinen ym. 2016: 37). Merkitysten rakentumisen kannalta tärkeä osa kontekstia on toiminnan välitön vuorovaikutuskonteksti - kaikki ne vuorovaikutuksen rakenteelliset ominaisuudet, jotka vaikuttavat kielellisten lausumien tai kehollisen toiminnan tulkintaan (Hollander 2004). Niinpä siinä missä aikaisempi fokusryhmien diskursiivinen tutkimus on eritellyt vuorovaikutuksessa rakentuvia merkityksiä ja osittain myös näiden merkitysten tuottamisen prosesseja, kysymys vuorovaikutuksen rakenteellisten ominaisuuksien vaikutuksesta näihin prosesseihin on jäänyt analyysissa taka-alalle. Tämä kysymys on sen sijaan erityisen keskeisellä sijalla etnometodologisen keskustelunanalyysin tutkimustraditiossa (Schegloff 2007; Sidnell 2010; Clift 2016; Stevanovic \& Lindholm 2016). Keskustelunanalyysissa tutkijoiden päähuomio on niissä vakiintuneissa tavoissa, joilla vuorovaikutuksen osallistujien vuorot säännönmukaisesti kytkeytyvät toisiinsa ja muodostavat toiminnallisia kokonaisuuksia eli sekvenssejä. Vuorovaikutuksen rakenteiden analyysia ei keskustelunanalyyttisissa tutkimuksissa kuitenkaan yleensä kytketä yhteisiin merkityksiin niiden sisällön osalta. Keskustelunanalyyttinen tarkastelu ei yksinään myöskään selitä sellaisia vuorovaikutuksellisia suuntautumisia, jotka ammentavat voimansa osallistujien aiemmin omaksumista kulttuurisista luokituksista, stereotypioista, normeista ja jäsennyksistä (Juhila ym. 2012: 32). 
Keskustelunanalyysin piirissä haastatteluvuorovaikutusta on tyypillisesti analysoitu yhteistoimintana, jossa osallistujat vaikuttavat puheellaan ja muulla toiminnallaan toisiinsa. Keskeinen havainto on, että haastattelijoiden toiminta vaikuttaa vuorovaikutuksen kautta siihen, millaista aineistoa taustalla olevan tutkimuksen käyttöön siirtyy (Antaki \& Rapley 1996; Mazeland \& ten Have 1996; Rapley \& Antaki 1998; Rapley 2004). Tutkimushaastattelu koostuu olennaisesti kysymyksistä ja vastauksista, ja keskustelun sujuvaan etenemiseen liittyviin velvoitteisiin molemmat osapuolet suuntautuvat yleensä moraalisella vakavuudella (Ruusuvuori \& Tiittula 2017: 51). Vaikka haastateltavalla on luonnollisesti valta määrittää haastattelijan kysymyksiin antamiensa vastausten sisältö, tavallisesti haastattelija kuitenkin antaa kaiken aikaa haastateltavalle kasvonilmeillään, nyökkäyksillään ja vastauspartikkeleillaan (esim. mm, joo tai niin) palautetta, joka osoittaa sanoman ymmärtämistä ja kehottaa jatkamaan puhetta. Tällainen haastattelijan toiminta - yhtä lailla kuin tällaisen toiminnan puute (Rapley 2001: 305) - vääjäämättä vaikuttaa haastateltavan vastausvuoroon. Niinpä keskustelunanalyyttisessa kirjallisuudessa korostetaan, ettei haastatteluvastaus ole itsenäinen tuotos, vaan haastattelijan ja haastateltavan yhteistoiminnan lopputulos (Ruusuvuori \& Tiittula 2017: 55-56). Keskustelunanalyysia on jonkin verran sovellettu myös fokusryhmähaastattelujen tutkimukseen (Myers 1998; Puchta \& Potter 2002; 2004), jolloin tutkijoiden kiinnostus on kohdistunut fokusryhmävuorovaikutuksen rakenteisiin ja ryhmän vetäjän osaan näiden rakenteiden hyödyntäjänä. Esimerkiksi Puchta ja Potter (2002) osoittivat, kuinka ryhmän vetäjän rohkaisevat kielelliset ja keholliset palautteet juuri tietynlaisille ja tietyllä tavalla ilmaistuille mielipiteille kertovat osallistujille, millaiset mielipiteet ovat odotuksenmukaisia ja kuinka ne tulisi ryhmäkeskustelussa ilmaista.

\section{Ehdotus lähestymistapojen yhdistämiseksi}

Tässä artikkelissa esittelemme lähestymistavan, jossa otamme fokusryhmäaineistojen diskursiivisen analyysin avuksi työkaluja keskustelunanalyysista. Käytännössä tämä tarkoittaa sitä, että pyrimme löytämään keinoja tarkastella ryhmäläisten puheen merkityssisältöjä siten, että puheenvuorojen muodostamien toimintakokonaisuuksien sekventiaalinen rakentuminen tulee samalla myös riittävässä määrin huomioiduksi. Sosiaalisen käytännön käsite on nähdäksemme avainasemassa rakennettaessa siltaa näiden lähestymistapojen välille (ks. myös esim. Halkier 2010). Siinä missä diskursiivisella käytännöllä tarkoitetaan sosiaalisesti vakiintunutta tapaa tuottaa lausumia tietyllä tavalla (Foucault 2005), korostuu sosiaalisten käytäntöjen käsitteessä sosiaalisen toiminnan yhteistoiminnallisuus (Reckwitz 2002). Sosiaalisten käytänteiden näkökulmasta niin "luonnollisissa" kuin tutkijoiden aloitteesta aikaansaaduissa vuorovaikutustilanteissa on siis lähtökohtaisesti kysymys samasta asiasta: toiminnasta, joka rakentaa sosiaalista maailmaa, mutta myös rakentuu tähän jo 
olemassa olevaan, vuorovaikutustilannetta ympäröivään maailmaan nojautuen. Ehdottamassamme lähestymistavassa olemme ensisijaisesti kiinnostuneita olemassa olevasta, vuorovaikutustilannetta ympäröivästä maailmasta - sellaisena kuin se meille näyttäytyy haastattelutilanteen paikallisen sosiaalisen toiminnan rakentumisen kautta.

\subsection{Analyyttiset työkalut}

Käytännössä lähestymistapamme fokusryhmäkeskusteluihin operoi kahdenlaisten kysymysten ympärillä. Ensimmäiset koskevat ryhmässä rakentuvia vuorovaikutusilmiöitä suhteessa esille nouseviin puheenaiheisiin ja näkemyksiin eli käsittelevät vuorovaikutuksen dynamiikkaa. Toiset koskevat niitä kulttuurisia merkityksiä, jotka ammentavat voimansa ennen kaikkea vuorovaikutustilanteen ulkopuolisesta sosiaalisesta todellisuudesta.

Vuorovaikutuksen dynamiikkaa koskien kysymme:

1. Synnyttävätkö jotkin ilmaukset tai näkemykset välittömän ryhmäkonsensuksen?

2. Seuraako joitakin ilmauksia ja näkemyksiä ongelmallisuutta vuorovaikutuksen etenemisessä?

3. Millaista ilmausten ja näkemysten muuntumista liittyy tilanteisiin, joissa vuorovaikutuksen sujuvuuden ongelmia ilmenee?

Näiden kysymysten tarkastelussa pidämme tärkeänä hyödyntää niitä käsitteellisiä työkaluja, joita keskustelunanalyyttisessa tutkimuskirjallisuudessa tarjotaan käytettäväksi ja joiden avulla fokusryhmien diskursiivisessa tutkimuksessa voidaan päästä tarkempiin tuloksiin. Tällaisia työkaluja nähdäksemme ovat ainakin seuraavat: vuorottelu, preferenssi ja responssin hakeminen.

Vuorottelu jäsentää kaikkea keskustelua. Vuorottelun yksityiskohtien tarkastelu kertoo paljon fokusryhmän osallistujien suuntautumisesta toinen toisiinsa ja puheena olevaan asiaan. Vuorottelun sujumattomuus, esimerkiksi pitkät hiljaisuudet, saattavat joissakin tapauksissa kertoa puheena olevan aiheen arkaluontoisuudesta. Päällekkäispuhunnan yksityiskohtien tarkastelu taas voi johtaa tutkijaa tekemään päätelmiä osanottajien välisestä erimielisyydestä tai - kuten usein on - samanmielisyydestä, jolle vuorovaikutuksen osapuolilla on omat itsenäiset perusteensa (Vatanen 2014). Erityisen voimakkaasta yksimielisyydestä saattaa monesti kertoa myös puheenvuoron jakaminen useamman puhujan kesken (Lerner 2002).

Preferenssi käsitteenä viittaa kysymykseen siitä, missä määrin seuraava puheenvuoro (tai muu vuorovaikutuksellinen teko) on odotuksenmukainen suhteessa aiempaan. Ajatuksena on, että preforoidut (odotuksenmukaiset) ja preferoimattomat (odotuksenvastaiset) puheenvuorot muotoillaan rakenteellisesti eri tavoin: pre- 
feroidut viivyttelemättä ja selittelemättä, preferoimattomat selitellen ja viivytellen (Pomerantz 1984a). Tarkastelemalla fokusryhmäläisten puheenvuorojen muotoilua ja tarkkaa ajoitusta suhteessa edelliseen puheenvuoroon voidaan näin ollen tehdä päätelmiä siitä, missä suhteessa puheenvuoron sisältö on suhteessa edellisen vuoron luomiin odotuksiin. Asia on oleellisesti sidoksissa, ei vain edellisen puheenvuoron statukseen puhetoimintona, vaan myös senhetkiseen puheenaiheeseen ja kaikkiin niihin kulttuurisiin normeihin ja odotuksiin, joita se tekee relevantiksi (Halkier 2010).

Responssin hakeminen on ilmiö, jota usein esiintyy tilanteissa, joissa puhuja ei saa puheenvuoroonsa odotuksenmukaista vastausta (Pomerantz 1984b). Vastausvuoron puuttumiseen voi olla monia syitä. Muut eivät ehkä ymmärrä puheenvuoroa siinä käytettyjen tuntemattomien käsitteiden vuoksi tai siksi, että puhuja on tehnyt virheellisiä, osallistujien tietoon liittyviä olettamuksia. Vastausvuoro voi jäädä puuttumaan myös yksinkertaisesti siitä syystä, että vastaanottaja ei ole puhujan kanssa samaa mieltä tai hän ei muuten halua vastata puheenvuoroon odotuksenmukaisella tavalla (Pomerantz 1984b: 152-153).

Vuorovaikutuksen dynamiikkaa koskevien kysymysten lisäksi tarkastelemme vuorovaikutustilanteen ulkopuolista sosiaalista todellisuutta ja sen tarjoamia kulttuurisia resursseja. Näiden osalta kysymme:

1. Millaisiin asioihin ryhmässä toistuvasti esille nostetut ilmaukset ja näkemykset liittyvät sisällöllisesti?

2. Millaisia merkityksiä ja moraalisia odotuksia niissä käytettyihin kategorioihin kiinnittyy?

3. Millaisia tunnistettavia merkityssysteemejä tai diskursseja osallistujat käyttävät hyväkseen toimintansa ymmärrettäväksi tekemisessä?

Kategoriat, joita jatkuvasti käytämme puhuessamme asioista, tapahtumista ja ihmisistä palvelevat vuorovaikutuksessa erilaisten funktioiden toteuttamista, kuten oikeuttamista tai kritisoimista. Sanat ovat "ideologisesti koodattuja" (Benwell \& Stokoe 2006: 113). Kategorioiden eksplisiittinen analyysi tarkoittaa sitä, että aineistosta etsitään ne kohdat, joissa kategoriaan viitataan julkilausutusti (Jokinen \& Juhila 2016: 306). Kategorioiden implisiittisen tuottamisen jäljille pääseminen on haasteellisempi tehtävä, jossa edellä esitellyt keskustelunanalyyttiset työkalut voivat olla erityisen hyödyllisiä. Esimerkiksi Holstein (1993) tarkasteli oikeuslaitoksissa tehtyjä, tahdonvastaista psykiatrista hoitoa koskevia päätöksiä kysyen, kuinka tulkinta terveen tai sairaan kategoriasta voidaan tehdä keskustelun rakenteellisen kulun perusteella. Kategorioihin kiinnittyvien merkitysten ja moraaliodotusten tutkimuksen avulla on mahdollista päästä käsiksi sellaisiin kulttuurisiin itsestäänselvyyksiin, jotka muutoin saattaisivat jäädä tutkijalta huomaamatta (Jokinen \& Juhila 2016: 306). 
Merkityssysteemi viittaa ajatukseen kielestä moniulotteisena järjestelmänä, jossa lukuisat rinnakkaiset ja joskus keskenään ristiriitaiset maailman merkityksellistämisen tavat rakentuvat osana erilaisia sosiaalisia käytäntöjä (Jokinen ym. 2016: 32-36). Historiallisesti painottuneissa vallan tai institutionaalisten käytäntöjen kriittisessä tutkimisessa merkityssysteemejä kutsutaan usein diskursseiksi (esim. Foucault 2005). Diskursiivisen psykologian tutkimusperinteessä merkityssysteemeistä taas käytetään useammin termiä tulkintarepertuaari (esim. Edley 2001). Vaikka merkityssysteemien identifioiminen fokusryhmäaineistosta edellyttää, että tutkija kiinnittää huomionsa ryhmäläisten nostamien puheenaiheiden substantiaalisiin sisältöihin, analyysissa liikutaan kuitenkin teemoittelun tuolle puolen: tutkijan päähuomio on niissä keinoissa, joiden avulla ryhmäläiset pyrkivät tekemään itseään toinen toisilleen ymmärrettäväksi.

\subsection{Fokusryhmäkeskustelun kulku}

Kun tietoa halutaan kerätä tavasta, jolla osallistujat puhuvat kulloisestakin aiheesta, voidaan fokusryhmän vetäjän ja osallistujien välisen vuorovaikutuksen minimoimisen ajatella vaikuttavan myönteisesti tulosten luotettavuuteen. Kuten aikaisempi tutkimus osoittaa, on osallistumisen rajoittaminen ryhmän vetäjälle todellisuudessa kuitenkin aina suuri haaste (esim. Ruusuvuori \& Tiittula 2017). Toisaalta vetäjän vaikutusta tilanteen kulkuun ei voida koskaan täysin estääkään. Itse olemme pyrkineet ratkaisemaan tätä osallistumisen problematiikkaa virikemateriaaleja käyttämällä.

Virikemateriaalien käytön on ajateltu maksimoivan spontaania vuorovaikutusta osallistujien kesken (Hyvärinen \& Löyttyniemi 2005; Valtonen 2005). Virike voidaan ymmärtää "merkeistä rakennetuksi kulttuurituotteeksi, joka valitaan ja valmistetaan haastatteluun viittaamaan tutkimuskohteeseen tai esittämään sitä" (Törrönen 2017: 233). Itse olemme valmistelleet fokusryhmän kululle rungon, joka on tyypillisesti pitänyt sisällään neljästä viiteen teemaa, joista haluamme osallistujien keskustelevan. Kutakin teemaa varten olemme valmistelleet virikemateriaalin, jonka esittämisen jälkeen olemme kehottaneet ryhmäläisiä keskustelemaan siitä, mitä materiaali tuo heille mieleen. Mikäli keskustelu on lähtenyt eri suuntaan kuin mikä on ollut tutkimuksen kannalta relevanttia, olemme fokusoineet sitä tarkentavin kysymyksin.

Virike on tärkeää valita niin, että se kutsuu puhetta tutkimuksen kohteena olevasta ilmiöstä, muttei kuitenkaan tee tätä liian läpinäkyvästi. Esimerkiksi eräässä tutkimuksessamme pyrimme herättämään keskustelua vuorovaikutuksessa ilmenevistä ihmisten välisistä valtasuhteista ja -hierarkioista. Emme kuitenkaan kysyneet tästä aiheesta tutkittavilta suoraan, vaan soitimme heille virikemateriaalina kaksi eri versiota samasta puheenvuorosta, joissa olimme muokanneet puhujien puheen sävelkorkeuksia siten, että ensimmäisessä versiossa puheenvuoron esittäjä kuulosti naiselta ja jälkimmäisessä mieheltä. Pohdittuaan hetken aikaa sitä, kuulostiko 
miespuhujan esittämä väite uskottavammalta kuin naispuhujan, osallistujat siirtyivät keskustelemaan siitä, millaisia muita uskottavuuseroja ihmisten välillä saattoi olla. Tämä taas johti heidät - toiveidemme mukaisesti - pohtimaan vallan ilmenemistä vuorovaikutuksessa. Virikemateraalin käytön avulla fokusryhmän vetäjä voi siis ikään kuin tarjoilla tiettyjä teemoja osallistujien kesken keskusteltavaksi (Valtonen 2005) ilman, että tulee johdatelleeksi osallistujien keskustelua liikaa kysymisellään.

\subsection{Analyysiprosessin kulku}

Fokusryhmän tuottaman vuorovaikutusaineiston analyysin aluksi videotallennetut keskustelut litteroidaan keskustelunanalyyttistä litterointitapaa noudattaen (ks. Liite). Tämän jälkeen aineistoa tarkastellaan ilman ennalta asetettuja tutkimuskysymyksiä, jolloin tutkijan huomio voi suuntautua aineistosta luontaisesti esiin nouseviin vuorovaikutusilmiöihin. Ajattelemme, että analyysissa on syytä keskittyä erityisesti niihin hetkiin, jolloin ryhmien jäsenet osoittavat responsiivisuutta (tai sen puutetta) toistensa vuorovaikutuksellisia kontribuutioita kohtaan, sen sijaan että vain vastaisivat haastattelijan tekemiin kysymyksiin. Tämä tekee mahdolliseksi tehdä luotettavampia päätelmiä niistä näkemyksistä, jotka syntyvät kunkin ryhmän kesken "aidosti" eli ilman, että ryhmänvetäjä näyttelisi merkittävää osaa näkemysten esiin kutsumisessa.

Virikemateriaalien avulla tuotettujen fokusryhmäkeskustelujen analyysissa poiketaan keskustelunanalyysin perinteisistä tiedonintresseistä ratkaisevasti siinä, että tätä kautta oletetaan olevan mahdollista saada tietoa haastattelutilanteen ulkopuolisista tilanteista ja tapahtumista (Törrönen 2017: 237-238). Erityisen keskeistä tulosten luotettavuuden ja yleistettävyyden näkökulmasta tässä lähestymistavassa on tarkastella konsensuksen (tai sen puutteen) muodostumista ryhmässä esille nousevista näkemyksistä. Ryhmäläisten ilmaiseman saman- ja erimielisyyden tarkastelu auttaa tutkijaa selvittämään, missä määrin tiettyyn näkemykseen liittyvä aineisto saavuttaa saturaation tietyn fokusryhmän sisällä (Onwuegbuzie ym. 2009). Ryhmien sisäisten näkemysten yleisyyden arvioinnissa on tärkeää tarkastella saman- ja erimielisyyden ilmausten esiintymistä jokaisessa kohdassa, jossa tietty näkemys esiintyy, erittelemällä laadullisesti kunkin ilmauksen esittämisen tapaa sekä sen saamaa vastakaikua ryhmäläisten keskuudessa. Näin tutkijan on mahdollista muodostaa käsitys näkemyksen yleisyydestä ryhmän sisällä. Mikäli tutkimuskysymyksen kannalta on keskeistä vertailla eri fokusryhmien välisiä eroja, pyritään kunkin fokusryhmän sisäinen saturaatio saavuttamaan ennen aineistojen välistä vertailua.

On kuitenkin tärkeää muistaa, että tutkimuksen tavoitteena on kuvata, tulkita ja tätä kautta luoda käsitystä niistä rutiininomaisista käyttäytymisen tavoista, joista vuorovaikutustilannetta ympäröivä sosiaalinen maailma rakentuu. Tarkasteltavan ilmiön luonteen vuoksi "totuuden" tai täydellisen ymmärryksen saavuttaminen sosiaalisista käytänteistä on jokseenkin mahdotonta, riippumatta siitä, kuinka paljon 
aineistoa kerätään. Tutkija voi jäljittää niistä vain johtolankoja, ja kukin tutkimus on siten aina tietoisesti "vajaa" ja keskeneräinen (Pynnönen 2013). Perinteiseen positivistiseen näkökantaan liittyvät validiteetti ja yleistettävyysnäkökulmat eivät siten ole tutkimuksen tavoitteena.

\section{Aineiston analyysi}

Seuraavaksi esittelemme kaksi esimerkkiä omista tutkimuksistamme, joissa olemme fasilitoineet ja analysoineet fokusryhmävuorovaikutusta osana laajempia tutkimushankkeitamme. Ensimmäisessä esimerkissä käsittelemme samanmielisyyden rakentumista vuorovaikutuksen dynamiikan sekä kulttuuristen kategorioiden ja merkityssysteemien yhteispelinä. Samalla havainnollistamme virikkeiden hyödyllisyyttä ryhmäläisten keskinäisen vuorovaikutuksen synnyttäjänä. Toisessa esimerkissä kuvaamme erimielisyystilanteiden hallinnointia fokusryhmävuorovaikutuksessa. Samalla näytämme, kuinka eri fokusryhmäkeskusteluiden välisiä hienovaraisia eroavaisuuksia voidaan analysoida. Analyysissa hyödynnämme edellä kuvaamaamme tutkimustapaa ja mainittuja keskustelunanalyyttisia ja diskursiivisen tutkimuksen työkaluja.

\subsection{Samanmielisyys: vuorovaikutuksen dynamiikka ja kulttuuriset resurssit}

Ensimmäiseksi analysoitava katkelma on tekeillä olevasta tutkimuksestamme, jossa pyrimme selvittämään erilaisissa työmarkkina-asemissa olevien ihmisten näkemyksiä mielenterveyskuntoutujista. Tutkimus on osa laajempaa hanketta, jossa tutkitaan mielenterveyskuntoutujien sosiaalisen osallisuuden mahdollisuuksia niin työelämässä kuin sen ulkopuolellakin olevissa vuorovaikutustilanteissa. Fokusryhmätutkimuksella, joissa mielenterveyskuntoutujien osallistuminen työelämään on keskustelun puheenaiheena, toivoimme saavamme täydentävää tietoa niistä piilevistä kulttuurisista odotuksista, jotka säännönmukaisesti värittävät mielenterveyskuntoutujien kohtaamia vuorovaikutustilanteita.

Katkelman fokusryhmäläiset ovat henkilöitä, joilla on takana 20-40 vuotta sellaisissa (tavanomaisissa) työpaikoissa, joissa työnantaja ei ole systemaattisesti osallistunut erityisiin toiminta- ja kuntoutusohjelmiin mielenterveyskuntoutujien työelämään integroimiseksi. Fokusryhmäläisiä on neljä ja he istuvat puolikaaren muodossa pöydän ympärillä järjestyksessä Erkki, Sanna, Sini ja Elisa. Istujia vastapäätä olevalle seinälle on heijastettu haastattelussa käytetyt virikemateriaalit, joissa esitellään Mielenterveyden keskusliiton 10.11.2017 julkaisemia Mielenterveysbarometrin tuloksia. 


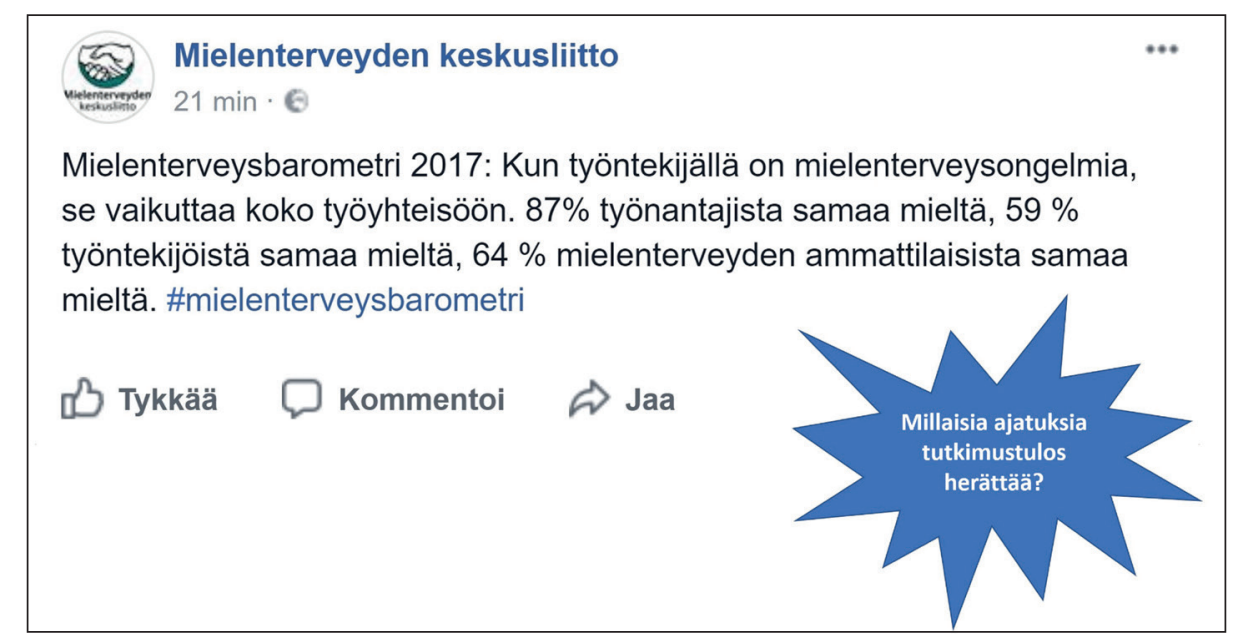

KUVA 1. Esimerkki virikemateriaalista fokusryhmähaastattelussa, jossa käsiteltiin mielenterveyskuntoutujien asemaa työelämässä (kuvakaappaus Mielenterveyden keskusliiton Facebook-seinältä 20.11.2017).

Otteen 1 alussa (r. 1-7) fokusryhmän vetäjä, Melisa, esittelee ryhmälle virikemateriaalina yhden tällaisen tuloksen (kuva 1), minkä jälkeen hän katsoo ryhmäläisistä poispäin antaen heidän itse valita, kuka aloittaa keskustelun ja milloin. Ote on keskustelun puolivälin tienoilta, ja sitä ennen osallistujille on esitetty virikkeitä samasta tutkimuksesta, joten keskustelun aihe ja haastattelijan tapa vetäytyä keskustelusta virikkeen esittämisen jälkeen ovat tässä vaiheessa osallistujille tuttuja. Virike herättääkin keskustelua miltei välittömästi.

OTE 1. Fokusryhmähaastattelu mielenterveyskuntoutujien asemasta työelämässä, TP2 02:47.

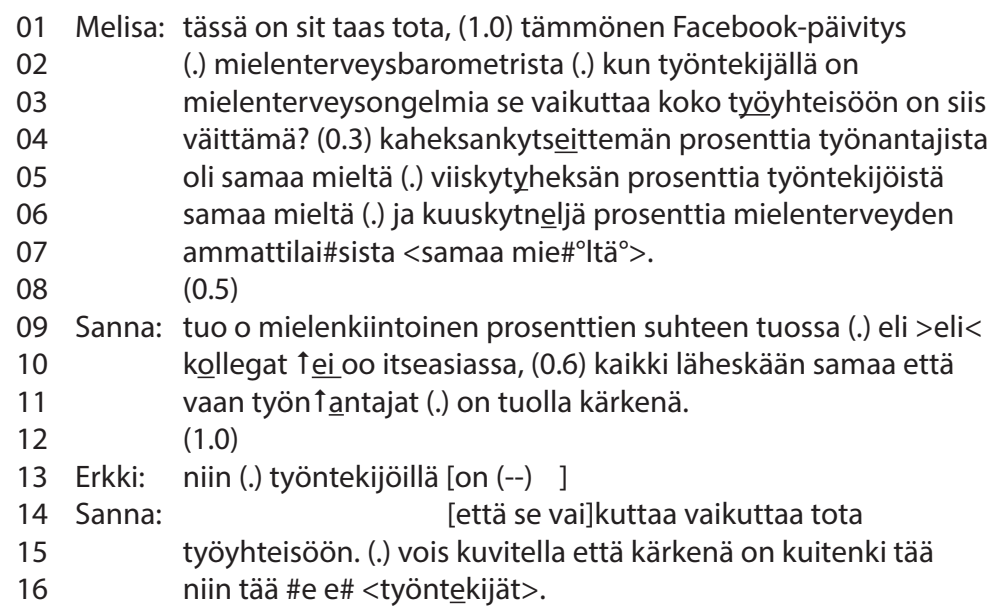


17 Erkki: nii.

18 Sanna: jotka on ninku [samalla [tasolla]

19 Sini: [(-) ]

20 Erkki: [samassa] tasolla niin. (.) ne

21 suvaitsisivat, (0.4) [paremmin ]

22 Sanna: [nii että he] suvaitsevat $\uparrow$ paremmin.

23 Erkki: joo.

24 Sanna: koska (.) ja se johtuu siitä että ollaan konkreettisesti

25 kuljetaan samalla tạsolla samoissa tehtävissä.

26 Erkki: nii. (--) se kielii siitä mitä (--) että ne haluaa pelata

$27 \quad$ va[rman päälle.]

28 Sanna: [niin varman ] päälle eli eli työnantajat haluavat .hh ööh siis

29 inhmisiä joilla ei ole mitään ongelmia eikä eikä eikä huolia eikä

30 murheita eikä ei ei lapsia eikä eikä .hh vanhuksia eikä

31 [eikä eikä vanhempia] sisaruksia

32 Erkki: [eikä tule raskaaksi]

33 Sanna: >eikä tule raskaaksi< ei[kä,]

34 Sini: [täy]s teho päällä. heh heh

35 Sanna: täys teho päällä et vaan kakskytvuotiaana niillä on .hh

kahdenkymmeneviiden vuoden työkokemus ja ja puhuvat €kymmentä kieltä€

37 .hh j(h)a osaavat myyä €itsensä ka- tota heh heh vaikka kuinka moneen

38 tehtävään€. (.) eli toi kertoo pikkasen siitä. (-) siitä tuo

$39 € \mathrm{Et}(\mathrm{h})$ yönantajien hh näkemys tuossa hhh .hh hhh€

$40 \quad$ ((Sini ja Elisa nyökkäilevät.))

Rivillä 9 yksi osallistujista, Sanna, kommentoi esitettyä virikemateriaalia arvioivalla vuorolla, kuvaten esitettyjä prosentteja "mielenkiintoisiksi". Samalla hän topikalisoi eron työnantajien ja työntekijöiden vastausten välillä: nimenomaisesti työnantajista suurin osa on sitä mieltä, että työntekijän mielenterveysongelmat vaikuttavat koko työyhteisöön. Sen sijaan muut työntekijät, joihin Sanna viittaa kategorialla "kollegat", eivät ota asiaan yhtä jyrkkää kantaa. Sannan vuoroa seuraavan lyhyen tauon (r. 12) jälkeen Erkki vastaa samanmielisyyttä ennakoivalla vuorolla (r. 13), joka jää kuitenkin kesken Sannan jatkaessa päällekkäispuhuntana oman näkemyksensä esittämistä. Riveillä 14-16 Sanna tähdentää, että työntekijöiden luulisi odotuksenmukaisesti olevan niitä, joihin työyhteisössä esiintyvät mielenterveysongelmat eniten vaikuttavat. Erkki osoittaa samanmielisyyttä (r. 17), ja Sannan tarkentaessa työntekijöiden olevan "samalla tasolla" (r. 18) hän osoittaa ymmärrystä toistamalla Sannan vuoron keskeisen sisällön (samassa tasolla nii, r. 20).

Yhteisesti tuotettu vuoro rakentaa Sannan ja Erkin välille voimakasta yksimielisyyttä (Lerner 2002). Puheen sisällön suhteen Erkki vaikuttaa kuitenkin ymmärtäneen Sannan hieman väärin: Erkki puhuu työntekijöiden suvaitsevaisuudesta konditionaalimuodossa (suvaitsisivat, r. 21), jonka Sanna korjaa indikatiivimuotoon (suvaitsevat, r. 22). Tämä kertoo siitä, että Erkki on todennäköisesti ymmärtänyt Sannan ajatuksenjuoksun jopa päinvastoin kuin Sanna. Vaikkei vuorovaikutuksessa esiintyvä rakenteellinen samanmielisyys näin ollen annakaan koherenttia kuvaa siitä 
sisällöstä, jonka ympärille samanmielisyys kietoutuu, oleellista on, että Erkki ja Sanna rakentavat yhteistoiminnallisesti tulkinnan, jonka mukaan mielenterveysongelmien työyhteisövaikutusten havaitsemisessa tai havaitsemattomuudessa on itseasiassa kyse suvaitsevaisuudesta tai suvaitsemattomuudesta. Näin tehdessään osallistujat hyödyntävät ja uudelleen tuottavat kulttuurissamme tunnistettavaa, erilaisuuden hyväksymistä korostavaa diskurssia. Työntekijät kulkevat kollegiaalisesti toistensa rinnalla, "samalla tasolla samoissa tehtävissä" (r. 24-25).

Rivillä 26 Erkki vaihtaa näkökulmaa työntekijöiden suvaitsevaisuuden käsittelystä työnantajien suvaitsemattomuuteen, todeten työnantajien haluavan "pelata varman päälle". Sanna tarttuu tähän välittömästi. Hän toistaa sanat "varman päälle"ja eksplikoi työnantajien asenteen: työntekijöiksi ei haluta ihmisiä, joilla on minkäänlaisia ongelmia (r. 28-31). Erkki ja Sanna yhteisesti kuvaavat työnantajan näkökulmasta ongelmallisiksi kuvittelemiaan työntekijöitä, mihin nyt myös Sini yhtyy todeten naurahtaen, että työntekijöiksi odotetaan niitä, joilla on "täys teho päällä" (r. 34). Tämäkin kuvaus tuotetaan yhteistoiminnallisesti ikään kuin yhtenä laajana puheenvuorona (Lerner 2002). Sanna jälleen toistaa Sinin ajatuksen ja ryhtyy kuvaamaan humoristiseen sävyyn, millainen tarkalleen ottaen tällainen "täystehoinen" työntekijä olisi (r. 35-39). Näin osallistujat yhteistoiminnallisesti ironisoivat markkinavoimien kapitalistista diskurssia ja asettuvat sitä vastaan. Ahdasmielisen, rahanahneen työnantajan kategoriaan kiinnittyvät merkitykset ovat ryhmäläisille selkeästi tunnistettavia. Niin Sini kuin Elisakin, jotka muutoin ovat olleet katkelman ajan hiljaa, nyökyttelevät ja osoittavat samanmielisyyttä myös kasvojen ilmeillään. Tämän kategorian kautta Mielenterveysbaromentin sinänsä neutraalit tulokset rakentuvat ryhmäläisten vuorovaikutuksessa voimakkaan moraalisiksi ja ideologisiksi. Työnantajien suhteellisen suuri samanmielisyys mielenterveysongelmien työyhteisövaikutuksia esittävän väittämän kanssa näyttäytyy tästä näkökulmasta yhtä epäreiluna asiana kuin ihmisen normaaliin elämänkaareen liittyvien asioiden, kuten lasten hankinnan, kieltäminen.

Otteen loppuosa kertoo siis ryhmäläisten vahvasta ryhmäkonsensuksesta. Yhteisesti tuotettu puheenvuoro ja runsas päällekkäispuhunta, jossa puhujat peilaavat tarkasti toistensa puheen sisältöjä, toimivat voimakkaana viestinä puhujien jakamista, asiaa koskevista mielipiteistä ja ennakkokäsityksistä. On ikään kuin erimielisyyden mahdollisuutta ei edes olisi. Huomionarvoista on, että tässä tilanteessa tällainen voimakas yksimielisyys syntyi siitä huolimatta, että sen rakentaminen lähti alun perin liikkeelle väärinkäsityksestä koskien samanmielisyyden asiasisältöä. Vuorovaikutuksellisesti rakentunut samanmielisyys toimi näin katalysaattorina edesauttamassa myös sisällöllisen samanmielisyyden löytymistä. Yksimielisyys on preferoitua, ja sen tuottamiseksi ryhmäläiset hyödynsivät kulttuurisesti tunnistettavia kategorioita ja merkityssysteemejä joustavasti. 


\subsection{Erimielisyys: vuorovaikutuksen dynamiikka ja kulttuuriset resurssit}

Eräässä toisessa tutkimuksessamme (Stevanovic \& Weiste 2017) tarkastelimme keskustelunanalyyttisiin datasessioihin liittyviä julkilausumattomia normeja ja ihanteita ekspertti- ja noviisitutkijoiden muodostamissa fokusryhmissä. Tässäkin tutkimuksessa käytimme fokusryhmäkeskustelujen ohjaamiseen virikemateriaalia - äänitallennettuja aitoja vuorovaikutustilanteita keskustelunanalyyttisistä datasessioista pyytäen ryhmäläisiä vapaasti reflektoimaan kuulemaansa.

Keskustelunanalyyttisessa datasessiossa ideana on, että kaikki paikallaolijat yhdessä tuottavat analyysia kulloinkin käsiteltävänä olevasta vuorovaikutuskatkelmasta. Noviisiryhmän jäsenet nostivat kuitenkin keskustelussaan esiin sen ikävän mahdollisuuden, että jonkun osallistujan analyyttiset havainnot saatetaan jättää huomiotta. Ote 2 havainnollistaa tätä näkökulmaa. Ennen otteen alkua yksi osallistujista, Kia, on kertonut tilanteista, joissa hänen puheenvuoronsa jälkeen on datasessiossa oltu aivan hiljaa. Tilanteesta ei kuitenkaan Kian omien sanojen mukaan jäänyt hänelle "traumaa", koska muut olivat kuitenkin nyökkäilleet tai katsoneet litteraattia miettivän näköisinä. Hetkeä myöhemmin Tua toteaa olevan paljon pahempaa, jos oma puheenvuoro tulisi täysin sivuutetuksi (r. 1-2).

OTE 2. Keskustelunanalyysin noviisien haastattelu 30:18.

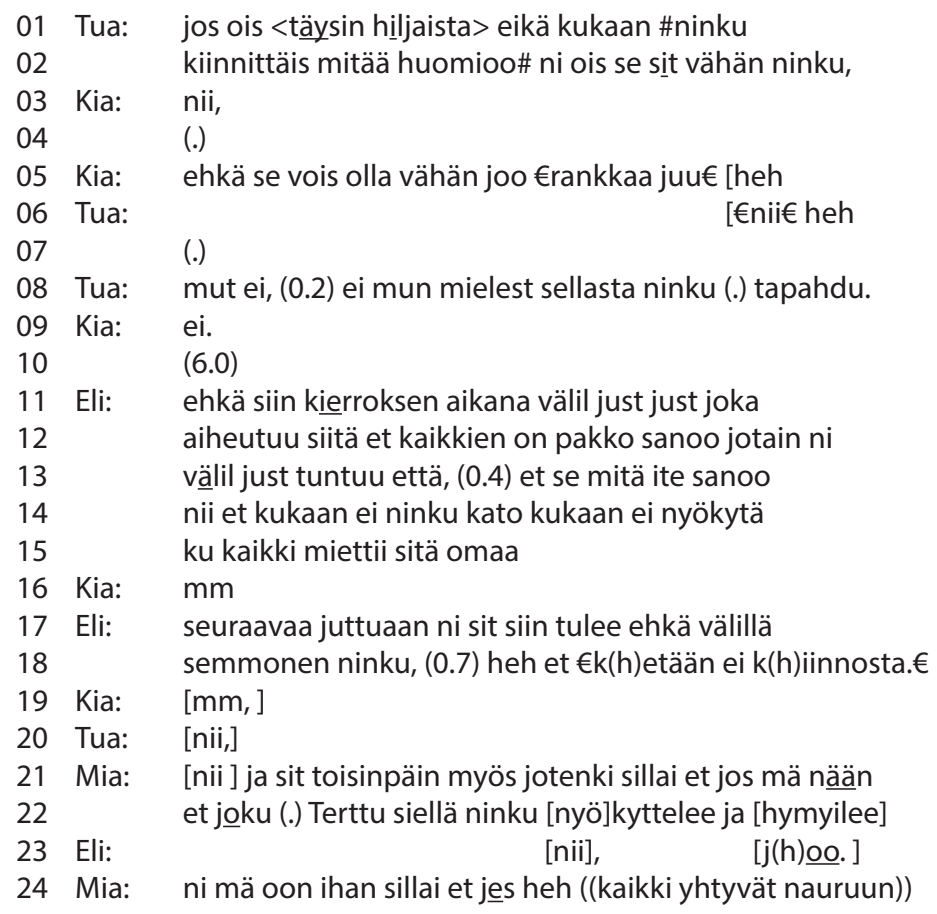


Kia yhtyy Tuan näkemykseen toteamalla hänen kuvaamansa tilanteen kieltämättä "rankaksi" (r. 3 ja 5). Kia esittää samanmielisen kannanottonsa kuitenkin huvittuneena implikoiden, että kyse on lähinnä hypoteettisesta kauhuskenaariosta. Tällaisen implikaation kanssa samansuuntaisesti Tua toteaakin, ettei tällaista tapahdu (r. 8), ja Kia yhtyy välittömästi näkemykseen (r. 9). Näin Kia ja Tua yhteisesti rakentavat käsitystä, jonka mukaan osallistujien responssin puutteesta valittaminen on joko täysin aiheetonta tai merkki sellaisesta ylisensitiivisyydestä, joka kuvaa mitättömistä asioista traumatisoituneita ihmisiä (huom. Kian aikaisempi puhe kokematta jääneistä "traumoistaan"). Tätä käsitystä vasten muodostuu sosiaalisesti ongelmalliseksi toiminnaksi todeta, että piinallisia datasessiohiljaisuuksia on olemassa. Hetken päästä Eli tekee kuitenkin juuri näin: hän toteaa, että datasessioissa todella tapahtuu toisten esittämien huomioiden täydellistä sivuuttamista, mutta hän esittää käytökselle legitiimin syyn: kukin keskittyy niin kovasti omiin sanomisiinsa, ettei voimavaroja riitä muiden kuuntelemiseen (r. 11-15, 17-18).

Esimerkissä Eli ammentaa kulttuurisesti tunnistettavasta, ihmisen yleistä egosentrisyyttä korostavasta merkityssysteemistä, ja ihmisyydestään johtuen myös Eli tulee käytännössä asemoiduksi samalle viivalle potentiaalisten traumojen aiheuttajien kanssa. Näin Eli tehokkaasti välttää tuottamasta itseään kategorian "muiden käytöksestä traumatisoitunut yliherkkä" edustajana, vaikka hän toteaakin ongelmien olemassaolon. Vaikka Elin kuvaus datasessioon osallistujien käyttäytymisestä on sävyltään kielteinen, hän kuitenkin pehmentää sitä käyttämällä sanoja ehkä (r. 11) ja välillä $(r .11,13,17)$ sekä tuottamalla kuvauksensa kielteisimmän ilmauksen ketään ei kiinnosta viiveellä ja nauraen vaivautuneesti (r. 18). Tämä osoittaa, että myös Eli itse suuntautuu kuvaukseensa vuorovaikutuksellisesti ongelmallisena (Pomerantz 1984a; Potter \& Hepburn 2010).

Kia ja Tua yhtyvät Elin näkemykseen minimaalisesti (r. 16, 19-20). Mia sen sijaan kääntää Elin näkökulman tasan päinvastaiseksi viittaamalla kokemuksiinsa, joissa muut datasessioon osallistujat, kuten eräs Terttu-niminen professori, ovat nyökkäilleet ja hymyilleet vastauksena Mian analyyttisiin huomioihin (r. 21, 22, 24). Näin toimiessaan Mia ammentaa diskurssista, jossa ihminen näyttäytyy prososiaalisena, toisten ihmisten tunnustusta kaipaavana olentona, samalla kun hänen raportoimiensa kokemusten positiivisuus implikoi, ettei tällaisessa sosiaalisessa sensitiivisyydessä ole kuitenkaan kysymys muiden käytöksen aiheuttamasta traumatisoitumisesta. Näin Mia onnistuu yhdistämään toisiinsa yhtäältä Kian ja Tuan myönteisen datasessiovuorovaikutuksen kuvauksen ja toisaalta Elin implikoiman näkemyksen siitä, että on normaalia myös olla jossain määrin sensitiivinen toisten ihmisten käyttäytymisessä ilmenevälle välinpitämättömyydelle. Mian kuvaus on vuorovaikutuksellisesti ongelmaton, mistä kertovat muiden ryhmäläisten vapautuneesti nauraen tuottamat samanmielisyyden ilmaukset (r. 23-24). 
Koska datasessioiden yleinen normi on toivottaa kaikkien osallistujien analyyttiset havainnot tervetulleiksi, fokusryhmien jäsenten vaikutti olevan vaikeaa puhua tilanteista, joissa näin ei tapahtunut. Kuitenkin siinä missä noviisiryhmässä pahimpana skenaariona mainittiin täydellinen vaikeneminen, eksperttiryhmässä tuotiin esiin myös avoimen konfliktin mahdollisuus. Silti muiden ryhmäläisten vaisu reagointi aiheeseen implikoi, etteivät tällaiset tilanteet ehkä kuitenkaan ole datasessiovuorovaikutukselle kovin leimallisia ja ettei omien eriävien mielipiteiden esiin tuomisesta pidättäytyminen ainakaan ole aihe, josta on syytä tehdä numeroa. Tällainen suuntautuminen tulee esiin otteessa 3, jonka alussa yksi keskustelunanalyysin ekspertti, Ani, kuvaa omia negatiivisia datasessiokokemuksiaan (r. 1-7).

OTE 3. Keskustelunanalyysin eksperttien haastattelu 37:38.

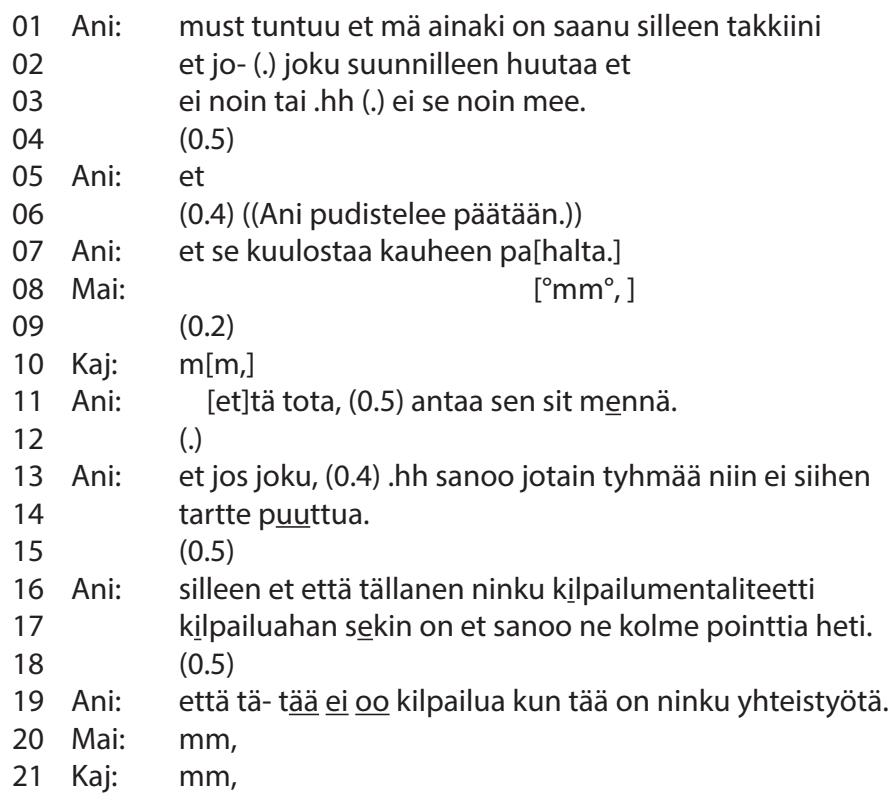

Riveillä 1-3 Ani kuvailee datasessiokokemustaan, jossa hänen analyyttisiin huomioihinsa oli vastattu kielteisellä kommentoinnilla, jopa huutamisella, ja josta hän kertoo loukkaantuneensa (oon saanu silleen takkiini, r. 1). Tämän jälkeen Ani arvostelee tällaista käytöstä: hän keskeyttää puheensa, pudistaa päätään ja tuottaa kriittisen arvion (kuulostaa kauheen pahalta, r. 7), johon Mai ja Kaj liittyvät vain minimaalisesti $(m m$, r. 8, 10). Ani jatkaa kerrontaansa toteamalla, että vaikka joku sanoisi "jotain tyhmää", ei sellaiseen tarvitse puuttua, vaan sen voi "antaa sit mennä" (r. 11-14). Toisin sanoen ketään ei tulisi suoraan haastaa asiaankuulumattomista tai vääränlaisista analyyttisistä huomioista, vaan ne voisi ennemmin jättää vain huomiotta. Kiinnostavasti Anin kuvaus normatiivisesti ihanteellisesta tavasta hallita erimielisyyksiä on 
lopputulokseltaan sisällöllisesti yhteneväinen noviisien mainitseman kauhuskenaarion kanssa, jossa analyyttiset havainnot kuitataan hiljaisuudella. Käsityksemme mukaan tämä eroavaisuus noviisi- ja eksperttiryhmien välillä kertoo monia asioita tiedeyhteisöön sosiaalistumisen prosesseista (ks. Stevanovic \& Weiste 2017). Toisaalta Ani kuitenkin korostaa tarvetta suojella ihmisiä muiden erimielisyyden ilmauksilta. Näin ollen Ani itse onkin vaarassa tulla implisiittisesti kategorisoiduksi muiden ihmisten käytökselle ylisensitiiviseksi yksilöksi, joka - noviisiryhmässä esitettyjä termejä hyödyntäen - "traumatisoituu" helposti.

Anin kuvaus saa vain vähän vastakaikua muilta. Vastavuoroisuuden puute voi osittain johtua tavasta, jolla Ani muotoilee valituksensa: otteen alussa oleva "tyhmä" henkilö on Ani itse. Vaikka Ani myöhemmin muuttaa perspektiivin kolmanteen persoonaan (joku sanoo jotain tyhmää, r. 13), saattaisi samanmielisyys Anin näkemyksen kanssa implikoida samanmielisyyttä myös Anin alkuperäisen itsemoitteen kanssa (ks. Pomerantz 1984a). Toinen syy responssin puutteeseen saattaa olla myös aiheen vaikeus itsessään: on ongelmallista puhua datasessiovuorovaikutuksesta kriittisesti niiden kollegoiden kanssa, joiden kanssa on istuttu samoissa datasessioissa monet kerrat. Lisäksi sikäli kuin toisten käyttäytymiselle ylisensitiivisen hysteerikon kategoria voidaan laajemminkin nähdä välttämisen arvoisena, on ymmärrettävää, että puhujan "takkiin saamisen" kokemuksen jakamisesta halutaan pidättäytyä. Huomionarvoista onkin, että vuorovaikutussekvenssi saadaan vietyä päätökseen vasta, kun Ani muuttaa näkökulmaansa. Ensin hän valittaa "kilpailullisesta mentaliteetista", jolloin osallistujat saattavat sanoa kaikki analyyttiset havaintonsa heti (r. 16-17), mutta tämäkin valitus tulee vastaanotetuksi hiljaisuudella. Vasta kun Ani toteaa, että datasessioiden tulisi kilpailun sijaan olla yhteistyötä (r. 19), muut ilmaisevat olevansa Anin kanssa samoilla linjoilla ( $m m$, r. 20-21). Reaktio kertoo niistä itsestään selvästi positiivisista, moraalisesti korkea-arvoisista merkityksistä, joita "yhteistyöhön" toiminnan kategoriana kiinnittyy.

Esimerkki havainnollistaa ryhmän keskinäisen vuorovaikutusdynamiikan vaikutusta siihen, millaisiin kulttuurisiin resursseihin ryhmäläiset tukeutuvat näkemystensä ymmärrettäväksi tekemisessä. Vastavuoroisuuden puutteen vallitessa responssin hakeminen voi johtaa puhujan vaihtamaan näkemystensä painopisteitä ja niiden tueksi ammennettavia kulttuurisia kategorioita ja merkityssysteemejä moneen kertaan. Samalla vuorovaikutuksen dynamiikka kuitenkin tuottaa ja uusintaa omanlaistaan normatiivisuutta. Tässä tapauksessa ryhmäläiset - kaikki keskustelunanalyysin asiantuntijoita - tuottivat keskustelunsa metatasolla kaiken aikaa myös implisiittistä kuvausta siitä, millaista keskustelunanalyytikoiden yhteisön jäsenten keskinäisen vuorovaikutuksen tulisi olla. Niistä näkemyksistä ollaan hiljaa, joihin ei voida yhtyä, ja siihen tartutaan, mihin voidaan yhtyä. Sama ihanne, jonka Ani nosti puheen sisällön tasolla eksplisiittisesti esiin, tuotettiin tilanteessa implisiittisesti myös vuorovaikutuksen dynamiikan keinoin. On oletettavaa, että erityisen voimakkaita moraa- 
liodotuksia on läsnä erityisesti tällaisessa implisiittisessä, normatiivisesti oikeanlaisen keskustelunanalyytikon kategorian tuottamisessa.

\section{Loppupäätelmät}

Tässä artikkelissa olemme esitelleet lähestymistavan, jossa fokusryhmäaineistojen analyysiin yhdistetään metodisia työkaluja fokusryhmien diskursiivisesta tutkimuksesta ja keskustelunanalyysista. Olemme toisin sanoen pohtineet mahdollisuuksia operoida keskustelun sisällön ja vuorovaikutusdynamiikan välimaastossa. Tällaisia pyrkimyksiä on viime vuosina esiintynyt monilla muillakin keskustelun tutkijoilla (ks. esim. Wilkinson \& Kitzinger 2003; Halkier 2010; Lindegaard 2014). Vaikka vuorovaikutusilmiöiden ymmärtämiseksi onkin tarkasteltava meneillään olevaa toimintaa ja sitä, kuinka osallistujien lausumat yhtäältä rakentavat toimintaa ja toisaalta rakentuvat suhteessa siihen, tämä ei yksinään riitä. Vuorovaikutusaineiston kokonaisvaltainen analyysi edellyttää myös keskittymistä siihen, kuinka vuorovaikutustilanteen ulkopuolisesta maailmasta ammentavat kulttuuriset resurssit, kuten kategoriat ja merkityssysteemit, kietoutuvat osallistujien argumentaatioon ja niiden sisältöihin. Samalla on kuitenkin myös muistettava, että vuorovaikutustilannetta edeltävä ja sitä ympäröivä maailma on jotakin sellaista, joka näyttäytyy tutkijalle vain ja ainoastaan keskustelutilanteen paikallisen sosiaalisen toiminnan rakentumisen kautta.

Fokusryhmäkeskustelujen nauhoitukset tarjoavat siis rikkaan ja monipuolisen aineiston sosiaalisen todellisuuden ylläpitämisen prosessien tutkimiseen. Aineiston tuottamisen ensimmäinen edellytys luonnollisesti on, että osallistujat saadaan puhumaan keskenään. Luontevan keskustelun syntymiseen vaikuttaa osallistujien määrä (ks. Krueger 1994), mutta kokemuksemme mukaan myös se, että ryhmäläisillä on jonkinlainen jaettavissa oleva kokemus haastattelun kohteena olevasta asiasta. Samalla on toki hyvä, että haastateltavat pystyvät tuomaan tutkittavaan asiaan erilaisia näkökulmia (Valtonen 2005).

Tässä artikkelissa ehdottamamme tapa käyttää virikemateriaaleja ryhmäläisten keskustelun synnyttämiseen toimii kokemuksemme mukaan hyvin. Erityisen suositeltavia virikkeet ovat silloin, kun tutkija pyrkii saamaan tietoa ryhmäläisten jakamista käsityksistä ja normatiivisista odotuksista. Monet virikemateriaalit ovat omiaan provosoimaan arvioivia kannanottoja suhteessa siihen, kuinka tunnistettavia, yllättäviä, tavanomaisia tai harvinaisia virikemateriaalin esille tuomat näkökohdat ovat. Virikemateriaalien provosoimat, arvioivat puheenvuorot tarjoavat muille ryhmäläisille tilaisuuden ilmaista samanmielisyyttään puhujan kanssa. Ryhmäläisten reaktiot tai niiden puute, antavat näin ollen haastattelukysymyksiin verrattuna tutkijalle varsin suoran keinon päästä kiinni siihen, missä määrin erilaiset käsitykset ovat ryhmäläisten kesken jaettuja. Samalla tietenkin myös ne hetket, jolloin edellisen virikeaineiston esittämisestä on kulunut jo jonkin aikaa ja keskustelu etenee spontaa- 
nisti, antavat erityisen arvokasta tietoa osallistujille itselleen tärkeistä asioista. Sikäli kuin ryhmänvetäjä jättää ryhmäläisille vastuun keskustelun eteenpäin viemisessä ja ryhmäläisetkin suhtautuvat haastattelijaan ainoastaan virikkeiden vaihtajana, edellä mainittuja hetkiä saattaa olla keskustelussa hyvinkin paljon. Lisäksi virikemateriaalien käyttö antaa tutkijalle mahdollisuuden "vakioida" omaa osallistumistaan tutkimukseen liittyvien fokusryhmäkeskustelujen sarjassa huomattavasti tehokkaammin kuin ääneen esitettyjen haastattelukysymysten avulla. On kuitenkin tärkeä muistaa, että tässäkin tapauksessa fokusryhmän vetäjä väistämättä antaa nonverbaalilla viestinnällään palautetta ryhmäläisille, mistä on syytä olla tietoinen analyysiä tehdessä.

Ehdottamassamme lähestymistavassa fokusryhmäaineistojen diskursiiviseen tutkimukseen huomion pääkohde on olemassa oleva, vuorovaikutustilannetta ympäröivä sosiaalinen maailma, jota rakennetaan sosiaalisten käytänteiden kautta. Tavoitteena on kuitenkin tarkastella ryhmäläisten puheen merkityssisältöjä siten, että myös vuorovaikutuksen omat lainalaisuudet tulevat analyysissa riittävässä määrin huomioiduksi. Tällaisessa tutkimusotteessa, jossa yhdistetään diskursiivisen ja keskustelunanalyyttisen tutkimustavan työkaluja, on haasteena pitää tutkimuksen kohteena oleva ilmiö riittävän fokusoituna. Vuorovaikutustilanteiden moninaisuus tarjoaa lukemattomia yksityiskohtia, joihin analyysivaiheessa voisi olla kiinnostavaa tarttua, ja tutkija voikin ikään kuin hukkua näiden yksityiskohtien erittelemiseen. Lisäksi sosiaalisten käytänteiden näkökulmasta myös monenlaiset keholliset ja mentaaliset toiminnot, materiaaliset artefaktit ja niiden käyttäminen sekä osallistujien entuudestaan omaksuma tiedollinen ja taidollinen ymmärrys liittyvät siihen samaan laajaan kudelmaan (Reckwitz 2002: 249-50), johon tässä artikkelissa käsitellyt kulttuuriset resurssit, kategoriat ja merkityssysteemit sekä vuorovaikutusdynamiikan säännönmukaisuudet kytkeytyvät. Vaikka yhden tutkijan lienee mahdotonta ottaa kaikkia sosiaalisten käytänteiden elementtejä omassa analyysissaan tasapuolisesti huomioon, toiveenamme on diskursiivisen tutkimuksen eri suuntausten välisen vuoropuhelun edistäminen tavalla, joka edistää kokonaisvaltaisen ymmärryksen saavuttamista sosiaalisen todellisuuden luonteesta ja sen ylläpitämisen mekanismeista.

\section{Kirjallisuus}

Agar, M. \& J. MacDonald 1995. Focus groups and ethnography. Human Organization, 54 (1), 78-86. https://doi.org/10.17730/humo.54.1.x102372362631282.

Antaki, C. \& M. Rapley 1996. "Quality of life" talk: the liberal paradox of psychological testing. Discourse and Society, 7 (3), 293-316. https://doi.org/10.1177/0957926596007003002.

Benwell, B. \& E. Stokoe 2006. Discourse and identity. Edinburgh: Edinburgh University Press. Berger, P. L. \& T. Luckmann 1967. The social construction of reality. London: Allen Lane.

Bloor, M., J. Frankland, M. Thomas \& K. Robson 2001. Focus groups in social research. London: Sage. 
Clift, R. 2016. Conversation analysis. Cambridge: Cambridge University Press.

Duggleby, W. 2005. What about focus group interaction data? Qualitative Health Research, 15 (6), 832-840. https://doi.org/10.1177/1049732304273916.

Edley, N. 2001. Analysing masculinity: interpretative repertoires, ideological dilemmas and subject positions. Teoksessa M. Wetherell, S. Taylor \& S. J. Yates (toim.) Discourse as data: a guide to analysis. London: Sage, 198-228.

Edley, N. \& M. Wetherell 1997. Jockeying for position: the construction of masculine identities. Discourse and Society, 8 (2), 203-217. https://doi.org/10.1177/0957926597 008002004.

Edwards, D. \& J. Potter 1992. Discursive psychology. London: Sage.

Fairclough, N. 1992. Discourse and social change. Cambridge: Polity Press.

Fern, E. F. 2001. Advanced focus group research. London: Sage.

Foucault, M. 2005. Tiedon arkeologia. Tampere: Vastapaino.

Frith, H. \& C. Kitzinger 1998. “Emotion work” as a participant resource: a feminist analysis of young women's talk-in-interaction. Sociology, 32 (2), 1-22. https://doi.org/10.1177/00 38038598032002005.

Grønkjær, M., T. Curtis, C. de Crespigny \& C. Delmar 2011. Analysing group interaction in focus group research: impact on content and the role of the moderator. Qualitative Studies, 2 (1), 16-30. https://doi.org/10.1515/atd-2015-0068.

Halkier, B. 2010. Focus groups as social enactments: integrating interaction and content in the analysis of focus group data. Qualitative Research, 10 (1), 71-89. https://doi. org/10.1177/1468794109348683.

Hollander, J. A. 2004. The social context of focus groups. Journal of Contemporary Ethnography, 33 (5), 602-637. https://doi.org/10.1177/0891241604266988

Holstein, J. A. 1993. Court-ordered insanity: interpretive practice and involuntary commitment. New York, NY: Aldine de Gruyter.

Hyvärinen, M. \& V. Löyttyniemi 2005. Kerronnallinen haastattelu. Teoksessa J. Ruusuvuori \& L. Tiittula (toim.) Haastattelu: Tutkimus, tilanteet ja vuorovaikutus. Tampere: Vastapaino, $189-222$.

Jayyusi, L. 1984. Categorization and the moral order. London: Routledge.

Juhila, K., A. Jokinen, \& E. Suoninen 2012. Kategoria-analyysin juuret. Teoksessa A. Jokinen, K. Juhila \& E. Suoninen (toim.) Kategoriat, kulttuuri ja moraali: johdatus kategoriaanalyysiin. Tampere: Vastapaino, 17-43.

Jokinen, A., K. Juhila \& E. Suoninen 2016. Diskursiivinen maailma: teoreettiset lähtökohdat ja analyyttiset käsitteet. Teoksessa A. Jokinen, K. Juhila \& E. Suoninen (toim.) Diskurssianalyysi: teoriat, peruskäsitteet ja käyttö. Tampere: Vastapaino, 25-50.

Jokinen, A. \& K. Juhila 2016. Diskurssianalyyttisen tutkimuksen kartta. Teoksessa A. Jokinen, K. Juhila \& E. Suoninen (toim.) Diskurssianalyysi: teoriat, peruskäsitteet ja käyttö. Tampere: Vastapaino, 267-310.

Kitzinger, J. \& R. S. Barbour 1999. Introduction: the challenge and promise of focus groups. Teoksessa R. S. Barbour \& J. Kitzinger (toim.) Developing focus group research: politics, theory, and practice. London: Sage, 1-20.

Krueger, R. A. 1994. Focus groups: a practical guide for applied research. London: Sage.

Lindegaard, L. B. 2014. Doing focus group research: studying rational ordering in focus group interaction. Discourse Studies, 16 (5), 629-644. https://doi. org/10.1177/1461445614538563.

Lerner, G. H. 2002. Turn-sharing: the choral co-production of talk-in-interaction. Teoksessa C. E. Ford, B. A. Fox \& S. A. Thompson (toim.) The language of turn and sequence. Oxford: Oxford University Press, 225-256. 
Madriz, E. 2000. Focus groups in feminist research. Teoksessa N. K. Denzin \& Y. S. Lincoln (toim.) Handbook of qualitative research. London: Sage, 835-851.

Mazeland, H. \& P. ten Have 1996. Essential tensions in (semi-)open research interviews. Teoksessa I. Maso \& F. Wester (toim.) The deliberate dialogue: qualitative perspectives on the interview. Brussels: VUB University Press, 87-113.

Morgan, D. L. 2010. Reconsidering the role of interaction in analyzing and reporting focus groups. Qualitative Health Research, 20, 718-722. https://doi. org/10.1177/1049732310364627.

Myers, G. 1998. Displaying opinions: topics and disagreement in focus groups. Language in Society, 27, 85-111. https://doi.org/10.1017/S0047404500019734

Mäntyranta, T. \& M. Kaila 2008. Fokusryhmähaastattelu laadullisen tutkimuksen menetelmänä lääketieteessä. Duodecim, 124, 1507-1513.

Onwuegbuzie, A. J., W. B. Dickinson, N. L. Leech \& A. G. Zoran 2009. A qualitative framework for collecting and analyzing data in focus group research. International Journal of Qualitative Methods, 8 (3), 1-21. https://doi.org/10.1177/160940690900800301.

Pietilä, I. 2010. Ryhmä- ja yksilöhaastattelujen diskursiivinen analyysi: kaksi aineistoa erilaisina vuorovaikutuksen kenttinä. Teoksessa J. Ruusuvuori, P. Nikander \& M. Hyvärinen (toim.) Haastattelun analyysi. Tampere: Vastapaino, 212-241.

Pietilä, I. 2017. Ryhmäkeskustelu. Teoksessa M. Hyvärinen, P. Nikander \& J. Ruusuvuori (toim.) Tutkimushaastattelun käsikirja. Tampere: Vastapaino, 111-130.

Pomerantz, A. 1984a. Agreeing and disagreeing with assessments: some features of preferred/dispreferred turn shapes. Teoksessa J. Maxwell Atkinson \& John Heritage (toim.) Structures of social action: studies in conversation analysis. Cambridge: Cambridge University Press, 57-101.

Pomerantz, A. 1984b. Pursuing a response. Teoksessa J. Maxwell Atkinson \& John Heritage (toim.) Structures of social action: Studies in conversation analysis. Cambridge: Cambridge University Press, 152-164.

Potter, J. \& A. Hepburn 2010. Putting aspiration into words: 'laugh particles', managing descriptive trouble and modulating action. journal of pragmatics, 42 (6), 1543-1555. https://doi.org/10.1016/j.pragma.2009.10.003.

Potter, J. \& M. Wetherell 1987. Discourse and social psychology: beyond attitudes and behaviour. London: Sage.

Puchta, C. \& J. Potter 2002. Manufacturing individual opinions: market research focus groups and the discursive psychology of evaluation. British Journal of Social Psychology, 41, 345-363. https://doi.org/10.1348/014466602760344250.

Puchta, C. \& J. Potter 2004. Focus group practice. London: Sage.

Pynnönen, A. 2013. Diskurssianalyysi: tapa tutkia, tulkita ja olla kriittinen. Working Paper N:o 379. Jyväskylän yliopiston kauppakorkeakoulu.

Rapley, M. \& C. Antaki 1998. "What do you think about...?": generating views in an interview. Text, 18 (4), 587-608. https://doi.org/10.1515/text.1.1998.18.4.587.

Rapley, T. 2001. The art(fulness) of openended interviewing: some considerations on analysing interviews. Qualitative Research, 1 (3), 303-323. https://doi. org/10.1177/146879410100100303.

Rapley, T. 2004. Interviews. Teoksessa C. Seale, G. Gobo, J. F. Gubrium \& D. Silverman (toim.) Qualitative research practice. London: Sage, 15-33.

Reckwitz, A. 2002. Toward a theory of social practices: a development in culturalist theorizing. European Journal of Social Theory, 5 (2), 243-263. https://doi. org/10.1177/13684310222225432.

Ruusuvuori, J. \& L. Tiittula 2017. Tutkimushaastattelu ja vuorovaikutus. Teoksessa M. Hyvärinen, P. Nikander \& J. Ruusuvuori (toim.) Tutkimushaastattelun käsikirja. Tampere: Vastapaino, 46-83. 
Sacks, H. 1992. Lectures on conversation (toim. G. Jefferson). Oxford: Basil Blackwell.

Schegloff, E. A. 2007. Sequence organization in interaction: a primer in conversation analysis. Cambridge: Cambridge University Press.

Sidnell, J. 2010. Conversation analysis: an introduction. Malden, MA: Wiley-Blackwell.

Smithson, J. 2000. Using and analysing focus groups: limitations and possibilities. International Journal of Social Research Methodology, 3 (2), 103-119. https://doi. org/10.1080/136455700405172.

Stevanovic, M. \& C. Lindholm (toim.) 2016. Keskustelunanalyysi. Kuinka tutkia sosiaalista toimintaa ja vuorovaikutusta. Tampere: Vastapaino.

Stevanovic, M. \& E. Weiste 2017. Conversation analytic data session as a pedagogical institution. Learning, Culture, and Social Interaction, 15, 1-17. https://doi. org/10.1016/j.lcsi.2017.06.001.

Sulkunen, P. 1990. Ryhmähaastattelujen analyysi. Teoksessa K. Mäkelä (toim.) Kvalitatiivisen aineiston analyysi ja tulkinta. Helsinki: Gaudeamus, 264-285.

Törrönen, J. 2017. Virikehaastattelu. Teoksessa M. Hyvärinen, P. Nikander \& J. Ruusuvuori (toim.) Tutkimushaastattelun käsikirja. Tampere: Vastapaino, 233-255.

Valtonen, A. 2004. Rethinking free time: a study on boundaries, disorders, and symbolic goods. Acta Universitatis Oeconomicae Helsingiensis, A-236. Helsinki: Helsinki School of Economics.

Valtonen, A. 2005. Ryhmäkeskustelut - millainen metodi? Teoksessa J. Ruusuvuori \& L. Tiittula (toim.) Haastattelu: tutkimus, tilanteet ja vuorovaikutus. Tampere: Vastapaino, 223-263.

Vatanen, A. 2014. Responding in overlap: agency, epistemicity and social action in conversation. Väitöskirja. Helsinki: Helsingin yliopisto, Suomen kielen suomalais-ugrilaisten ja pohjoismaisten kielten ja kirjallisuuksien laitos.

Wilkinson, S. 1998. Focus groups in health research exploring the meanings of health and illness. Journal of Health Psychology, 3 (3), 329-348. https://doi. org/10.1177/135910539800300304.

Wilkinson, S. \& C. Kitzinger 2003. Constructing identities: a feminist conversation analytic approach to positioning in action. Teoksessa R. Harré \& A. Moghaddam (toim.) The self and others: positioning individuals and groups in personal, political and cultural contexts. New York, NY: Praeger/Greenwood, 157-180.

Wight, D. 1994. Boys' thoughts and talk about sex in a working-class locality of Glasgow. Sociological Review, 42 (4), 702-737. https://doi.org/10.1111/j.1467-954X.1994. tb00107.x. 


\section{Liite: Litterointimerkit}

$\begin{array}{ll}\text { [ ] } & \text { päällekkäispuhunta } \\ \text { (.) } & \text { 0.2 sekuntia lyhyempi hiljaisuus } \\ (0.6) & \text { hiljaisuus sekunteina } \\ \text { hh } & \text { sisäänhengitys } \\ \text { hh } & \text { uloshengitys } \\ \text { €sana€ } & \text { puhuttu hymyilevällä äänellä } \\ \text { \#sana\# } & \text { puhuttu narisevalla äänellä } \\ \text { sa(h)na } & \text { naurua sanan sisällä } \\ ((\text { sana)) } & \text { litteroijan selityksiä } \\ \text { sana } & \text { äänteen painottaminen } \\ \text { sa- } & \text { kesken jäänyt sana } \\ <\text { sana> } & \text { ympäröivää puhetta hitaampi puhe } \\ >\text { sana< } & \text { ympäröivää puhetta nopeampi puhe } \\ { }^{\circ} \text { sana }{ }^{\circ} & \text { ympäröivää puhetta hiljaisempi puhe } \\ \uparrow & \text { puheäänen sävelkorkeuden nousu } \\ \text {, } & \text { tasainen loppusävelkulku } \\ . & \text { laskeva loppusävelkulku } \\ ? & \text { nouseva loppusävelkulku }\end{array}$

